\title{
Perspektif Pelaku Bisnis Perhotelan di D.I. Yogyakarta terhadap CSR
}

\author{
Adisty Ayu Apsari \\ Alumnus Program Studi Ilmu Komunikasi \\ Universitas Islam Indonesia (UII), Yogyakarta
}

\author{
Abdul Rohman \\ Dosen Program Studi Ilmu Komunikasi \\ Universitas Islam Indonesia (UII), Yogyakarta
}

\begin{abstract}
The development of Corporate Social Responsibility (CSR) has been nourished by various practices undertaken by private entities. Hotel is one of business sectors that have acclaimed performing CSR, however, they raise critiques as it is mainly in the form of charities. It can be caused by either misconception of CSR, lacking of resources, or other factors involving in the spectrum. This study attempts to reveal definition of CSR and its decision making at the management level, and constraints in the program delivery. It finds that most of hotel participating in the study defines CSR as corporate philanthropy, perceives it as important at strategic management level, and sees insufficient time, money, and beneficiaries as major constraints.
\end{abstract}

Keywords: CSR, philanthropy, strategic management, decision-making, charity

\begin{abstract}
Abstrak
Pengembangan Corporate Social Responsibility (CSR) telah dilakukan oleh para praktisi di lembaga atau perusahaan swasta. Perusahaan perhotelan, adalah salah satu sektor bisnis yang menyatakan telah melaksanakan CSR, namun aktivitas CSR mereka menuai kritik karena hanya berkisah pada bentuk kegiatan amal. Hal ini bisa terjadi baik oleh adanya miskonsepsi dalam CSR, kurangnya sumber daya, atau faktor lain yang berkaitan. Kajian ini mencoba mengungkap definisi CSR dan proses pengambilan keputusan mengenai CSR di level manajemen, serta hambatan yang dihadapi saat melaksanakan program. Kajian ini menemukan bahwa sebagian besar hotel yang berpartisipasi dalam riset mengartikan CSR sebagai aktivitas filantropi perusahaan, menganggapnya sebagai suatu hal yang penting dalam level manajemen strategis, serta melihat bahwa kurangnya waktu, dana, dan kemanfaatan, sebagai hambatan utama.
\end{abstract}

Kata Kunci: CSR, filantropi, manajemen strategis, pengambilan keputusan, kegiatan amal

\section{Pendahuluan}

Dewasa ini istilah Corporate Social Responsibility (CSR) sudah tidak asing lagi. CSR merupakan konsep dari aktivitas perusahaan sebagai wujud tanggung jawab atau kepedulian pada stakeholdernya dengan menyisihkan sebagian keuntungan perusahaan. Praktik CSR tidak lepas dari perhatian pelaku bisnis perusahaan perhotelan. Konsep dasar CSR pada awalnya memang dilatarbelakangi 
oleh motivasi perusahaan yang bersifat karitatif atau sumbangsih. Saat ini terdapat banyak kegiatan perusahaan perhotelan yang bersifat donasi terhadap masyarakat sekitar dengan mengatasnamakan program CSR.

Fenomena ini tidak terlepas dari kebijakan masing-masing perusahaan perhotelan. Bentuk-bentuk program yang dibentuk dan dijalankan melewati proses pengambilan keputusan di tingkat manajemen. Cara pandang masingmasing pihak pengambil keputusan terhadap CSR dapat dikatakan berbeda, dibuktikan dengan adanya perbedaan bentuk program yang dijalankan.

Pelaku bisnis perhotelan tentunya memiliki dasar pertimbangan sendiri mengenai program CSR yang dilaksanakan. Bisa jadi berbasis charity atau bentuk dari manajemen strategis perusahaan. Tulisan ini ingin membahas: a) Bagaimana pelaku bisnis perhotelan di provinsi Daerah Istimewa Yogyakarta mendefinisikan Corporate Social Responsibility?; b) Bagaimana pengambilan keputusan manajerial dilakukan?; dan c) Hambatan apa saja yang dihadapi oleh pelaku bisnis perhotelan dalam implementasi program CSR.

\section{Konsep Corporate Social Responsibility}

CSR merupakan konsep yang sudah banyak dilakukan oleh perusahaan sebagai bentuk tanggung jawabnya kepada lingkungan sekitar perusahaan berada. Meski demikian, definisinya sangat beragam. Menurut Kotler \& Lee, CSR adalah komitmen untuk memperbaiki kesejahteraan komunitas melalui praktikpraktik kebijakan bisnis dan dengan keterlibatan-keterlibatan dari sumbersumber perusahaan. Sementara itu, Ferrel \& Ferrel berpendapat bahwa CSR adalah kewajiban para pelaku bisnis untuk memaksimalkan dampak positif dan meminimalkan dampak negatif pada masyarakat. CSR juga dipahami sebagai cara sebuah perusahaan dalam mencapai keseimbangan atau integrasi dari ekonomi, lingkungan, dan persoalanpersoalan sosial dan dalam waktu yang sama bisa memenuhi harapan dari shareholder maupun stakeholder (dalam Nova, 2012: 309).

Terdapat enam kategori program CSR yang dijabarkan oleh Kotler dan Lee (2006) dalam Nova (2012: 320-321), yaitu:

a. Cause Promotion: Perusahaan menyediakan dana lainnya yang dimiliki perusahaan untuk meningkatkan kesadaran masyarakat terhadap suatu masalah sosial;

b. Cause Related Marketing (CRM): Perusahaan memiliki komitmen untuk menyumbangkan persentase tertentu dari penghasilannya untuk suatu kegiatan sosial berdasarkan besarnya penjualan produk; 
c. Corporate Social Marketing (CSM): Perusahaan mengembangkan dan melaksanakan kampanye untuk mengubah perilaku masyarakat dengan tujuan untuk mendorong perubahan perilaku masyarakat;

d. Corporate Philantrophy: Perusahaan memberikan sumbangan langsung dalam bentuk derma untuk kalangan masyarakat tertentu, yang biasanya berbentuk pemberian secara tunai, paket bantuan, atau pelayanan secara cuma-cuma;

e. Community Volunteering: Perusahaan mendukung dan mendorong pihak internal untuk secara sukarela menyisihkan waktu guna membantu organisasi-organisasi masyarakat lokal maupun masyarakat yang menjadi sasaran program; dan

f. Socially Responsible Business Practice: Perusahaan melakukan aktivitas bisnis melampaui yang diwajibkan oleh hukum dan melaksanakan investasi yang mendukung kegiatan sosial dengan tujuan meningkatkan kesejahteraan komunitas dan memelihara lingkungan hidup.

ISO 26000 menjabarkan elemen CSR meliputi: tata kelola organisasi, praktik terhadap pekerja, lingkungan, praktik operasi yang adil, isu-isu konsumen, pengembangan dan pelibatan masyarakat, serta hak asasi manusia (Prastowo \& Huda, 2011: 104-108). Ini mengindikasikan bahwa CSR berkaitan dengan pengambilan keputusan pada level manajerial.

Pengambilan keputusan manajerial secara umum meliputi: a) Identifikasi masalah; b) Pengumpulan dan penganalisisan data; c) Pembuatan alternatif-alternatif kebijakan yang nantinya akan dijadikan sebagai alternatif keputusan, dengan memperhatikan situasi lingkungan; d) Memilih satu alternatif terbaik; e) Melaksanakan keputusan; f) Memantau dan mengevaluasi hasil pelaksanaan keputusan (S.U.I.S, 1989: 39).

Sedangkan proses dasar pengambilan manajerial mencakup pembuatan diagnosa, pembatasan dan penentuan sumber masalah, pengumpulan dan penganalisisan fakta yang relevan dengan masalah, pengembangan dan pengevaluasian pemecahan alternatif yang paling memuaskan, serta implementasi alternatif ke dalam tindakan. Selain itu dijelaskan pula bahwa pengambilan keputusan manajerial diklasifikasikan dalam dua sifat (Stoner \& Freeman, 1994: 391-392), yakni pengambilan keputusan terprogram dan tidak terprogram.

Dalam praktiknya, implementasi program CSR memiliki beragam pengalaman. Praktik terbaik telah dilaksanakan namun tidak dipungkiri juga terdapat hambatan-hambatan yang dapat menimbulkan beragam dampak. Salah satu hambatan tersebut yakni terjebaknya 
pelaksana CSR oleh bias-bias, yakni kamuflase, generik, directive, lip service, dan kiss and run (Suharto, 2010: 55-56).

\section{Metode Penelitian}

Penelitian ini menggunakan pendekatan kualitatif deskriptif dan paradigma konstruktivisme. Penelitian dilakukan di Yogyakarta, tepatnya di 10 hotel berbintang, yaitu: Grand Quality Hotel Yogyakarta, Melia Purosani, Jayakarta Hotel, Inna Garuda Hotel, Royal Ambarukmo Hotel, Grand Aston Yogyakarta, The Phoenix Yogyakarta, Sheraton Mustika Yogyakarta, New Saphir Yogyakarta, dan Sahid Raya Yogyakarta. Narasumber dalam kajian ini adalah mereka yang terlibat dalam pengelolaan hotel dan aktivitas CSR seperti General Manager, Public Relations Officer, dan Manajer Sumber Daya Manusia (SDM). Data dikumpulkan melalui wawancara semi terstruktur secara tatap muka maupun melalui komunikasi bermediasi seperti telepon dan $e$-mail.

\section{Hasil dan Pembahasan}

\section{a. Definisi Corporate Social Responsibility}

Secara umum, hotel mendefinisikan CSR sebagai bentuk tanggung jawab sosial perusahaan terhadap lingkungan sekitar. Perusahaan melakukan kegiatan yang berfokus pada kegiatan sosial sebagai bentuk kepedulian dan tanggung jawab mereka terhadap masyarakat. Pada dasarnya kegiatan CSR hotel menjadi cerminan atas definisi mereka, diartikan dan dituangkan ke dalam tiap programnya. Kemudian dikategorikan berdasarkan konsep program masingmasing. Kategorisasi tersebut kemudian dikaitkan dengan elemen-elemen CSR yang disebut juga sebagai subjek inti dalam ISO 2600o. Definisi pelaku bisnis perhotelan di Provinsi DIY terhadap CSR dapat digambarkan sebagai berikut:

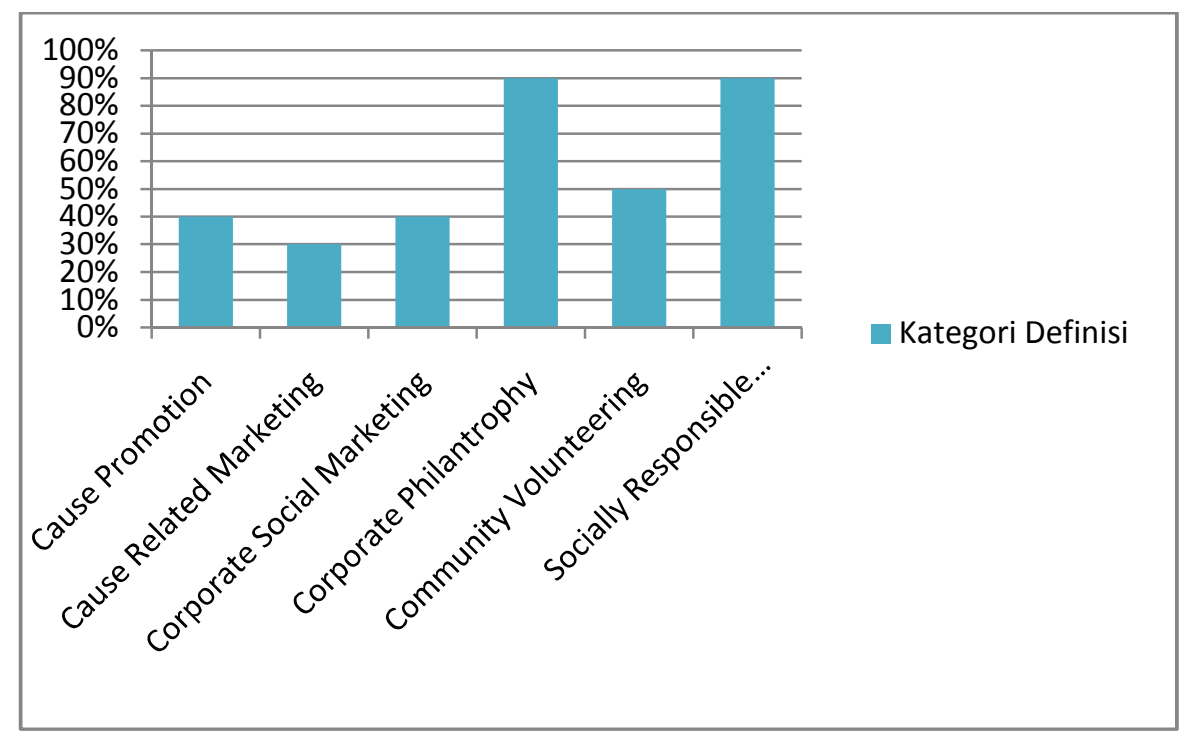

Gambar 1. Grafik Kategori Definisi CSR Perhotelan 
Grafik di atas menunjukkan, sebanyak 40\% dari perusahaan perhotelan yang ditelii mendefinisikan CSR dalam bentuk Cause Promotion dan juga Corporate Social Marketing. Sebanyak 30\% dari perhotelan Provinsi DIY memberikan definisi CSR nya ke dalam kategori Cause Related Marketing. Kemudian untuk CSR kategori Community Volunteering adalah sebanyak 50\%, sedangkan Corporate Philantrhopy danSocially Responsible Business Practice sebanyak 90\%. Dengan demikian, pelaku bisnis perhotelan masih mendefinisikan CSR ke dalam bentuk kegiatan filantropi perusahaan, yang juga merupakan praktik bisnis yang memiliki tanggung jawab sosial, walaupun terdapat juga CSR yang dilakukan dalam bentuk lainnya dengan jumlah persentase yang jauh lebih sedikit.

\section{b. Pengambilan}

\section{Manajerial}

Penjelasan tentang aspek manajerial program CSR yang dilakukan oleh hotel yang berpartisipasi di dalam riset, meliputi: 1) CSR dipandang sebagai bagian dari manajemen strategis; 2) Deskripsi proses pengambilan keputusan; 3) Divisi penanggung jawab; dan 4) isu pilihan dalam program CSR.

1. CSR sebagai Manajemen Strategis

Manajemen strategis adalah serangkaian keputusan dan tindakan manajerial yang menentukan kinerja perusahaan dalam jangka panjang (Hunger \& Wheelen, 2003). Sebagian besar pelaku bisnis perhotelan di Provinsi DIY menyatakan bahwa CSR telah menjadi bagian dari manajemen strategis perusahaan, yang notabene berada di bawah manajemen hotel internasional.

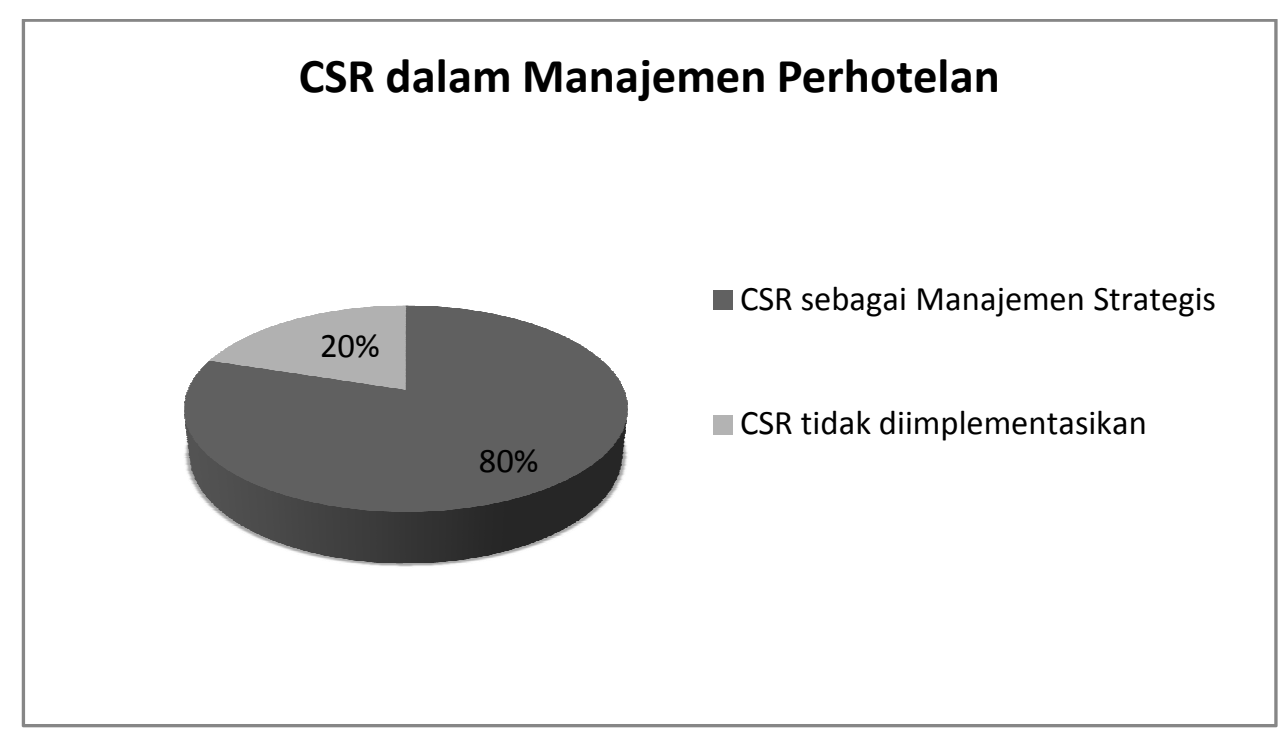

Gambar 2. CSR Sebagai Manajemen Strategis 
Grafik di atas menunjukkan bahwa sebanyak 80\% dari perhotelan di Provinsi DIY telah menjadikan CSR sebagai bagian dari manajemen strategis perusahaan mereka. Sedangkan 20\% lainnya belum menerapkan CSR secara tegas dalam manajemen perusahaannya.

CSR sebagai salah satu kebijakan manajemen perusahaan perhotelan dapat membantu memecahkan masalah yang dihadapi perusahaan. Masalah yang dimaksud di sini berkaitan dengan isu sosial berdasarkan hasil pengamatan manajemen perusahaan perhotelan, maupun isu sosial yang datang dengan sendirinya dan secara tidak langsung berdampak pada perusahaan.

2. Proses Pengambilan Keputusan Manajerial

Proses pengambilan keputusan manajemen perhotelan Provinsi DIY dapat digambarkan sebagai berikut:

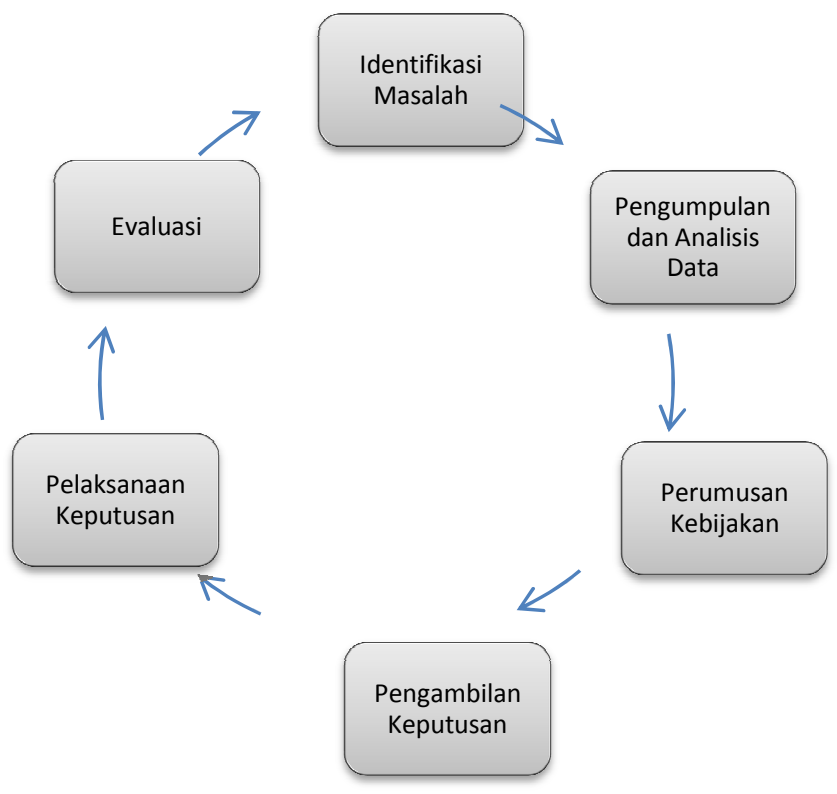

Gambar 3. Alur Proses Pengambilan Keputusan Manajerial Perhotelan

Sementara, pihak-pihak yang manajerial tersebut dapat digambarkan terlibat dalam alur proses keputusan sebagai berikut (lihat Gambar 4).

\section{Serikat \\ Pekerja / \\ Forkom}

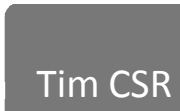

General

Manager

Tim CSR

Gambar 4. Pihak yang Terlibat dalam Pengambilan Keputusan Manajerial Perhotelan 
Proses pengambilan keputusan manajerial diawali oleh identifikasi permasalahan yang terjadi di lingkungan sekitar atau masyarakat pada umumnya. Biasanya dalam tahap ini, manajemen melakukan survei secara langsung yang diwakili oleh Serikat Pekerja. Serikat Pekerja merupakan organisasi internal perusahaan. Mereka menyuarakan apa yang menjadi permasalahan dalam lingkungan perusahaan dan didengarkan secara langsung oleh pihak perwakilan manajemen hotel, yang dalam penelitian ini biasanya diwakili oleh divisi tertentu, seperti HRD atau PR.
3. Divisi Penanggung Jawab CSR

Secara keseluruhan, pihak yang bertanggung jawab akan jalannya CSR sebuah perusahaan hotel adalah pimpinan tertinggi, yakni General Manager (GM). Namun tanggung jawab operasional dan pelaksanaan CSR di lapangan biasanya diserahkan kepada satu divisi tertentu. Tiap hotel biasanya menunjuk divisi yang berbeda atas pertimbangan manajemen masing-masing.

Grafik berikut menunjukkan jumlah persentase atas divisi yang bertanggung jawab dalam pelaksanaan CSR perusahaannya.

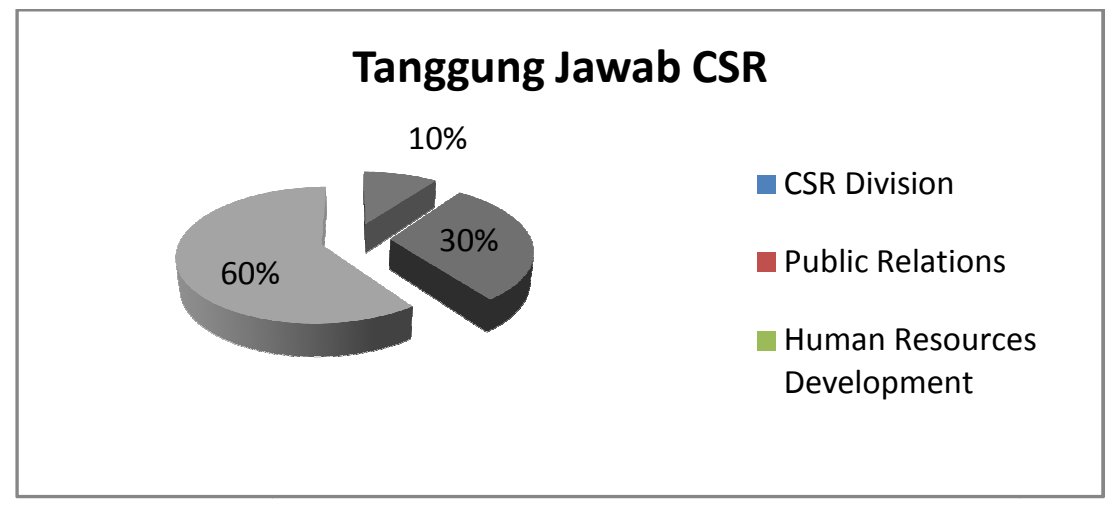

\section{Gambar 5. Divisi Penangung Jawab CSR}

Sebagian besar perusahaan hotel yang menjadi responden dalam riset ini memberi tanggung jawab pelaksanaan CSR kepada divisi Human Resources Development (HRD). Dapat dilihat dari grafik di atas bahwa sebanyak 60\% dari perhotelan di Provinsi DIY yang telah diwawancarai menempatkan pertanggungjawaban pelaksanaan CSR pada Divisi HRD. Kemudian sebanyak 30\% narasumber mengatakan bahwa tanggung jawab pelaksanaan CSR diberikan pada Divisi Public Relations.

Sebanyak $10 \%$ hotel membentuk divisi khusus yang bertanggung jawab akan pelaksanaan CSR, dengan koordinasi dan pembagian tanggung jawab bersama Divisi Public Relations. Melia Purosani, adalah satu hotel yang memiliki divisi khusus yang bertanggung jawab atas segala hal yang berkaitan dengan CSR. Divisi tersebut mereka namakan dengan 
Community Involvement Department.

Divisi ini khusus menangani CSR mulai dari perencanaan hingga implementasi, berkoordinasi dengan Divisi Public Relations. Adanya divisi khusus untuk CSR, oleh Hotel Melia Purosani dianggap memudahkan proses perencanaan, implementasi, hingga evaluasi program CSR. Sebab sudah ada orang-orang yang bertanggung jawab untuk semua tahapan pelaksanaan.
4. Isu Program CSR Perhotelan Provinsi DIY

Sebagian besar program CSR yang dilakukan berfokus pada isu sosial, lingkungan, kesehatan, ekonomi dan agama. Hanya beberapa hotel yang melakukan jenis kegiatan lainnya, seperti pendidikan, budaya, politik maupun pertahanan dan keamanan. Dapat digambarkan lebih jelas terkait persentase jenis isu program yang dilakukan oleh perhotelan di Provinsi DIY, sebagai berikut:

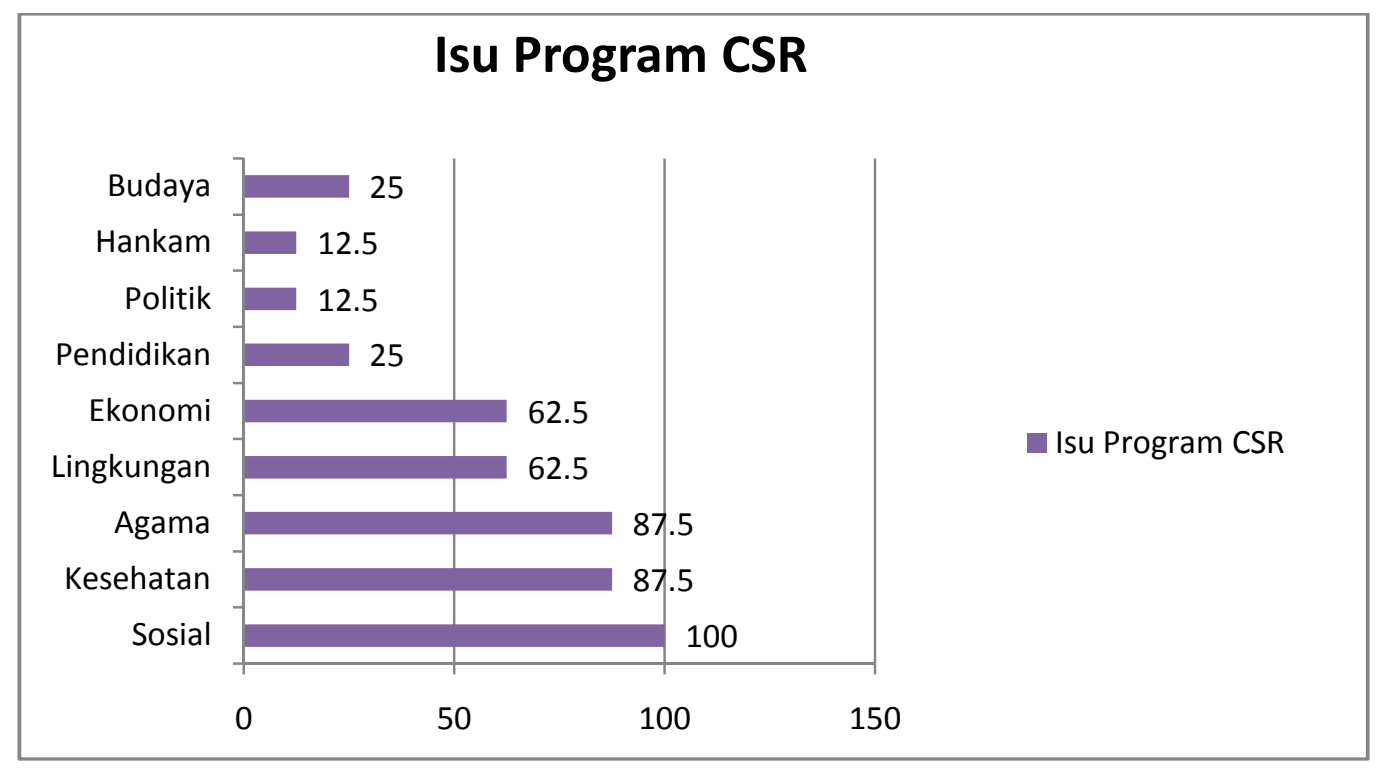

Gambar 6. Isu Program CSR Perhotelan

Grafik di atas menunjukkan bahwa sebagian besar perhotelan menyoroti hal yang umum seperti isu sosial, kesehatan, agama, lingkungan dan ekonomi. Walau demikian, mereka juga sudah mulai memiliki perhatian terhadap isu-isu yang memang bukan menjadi tanggung jawab mereka secara khusus. Dengan adanya partisipasi perhotelan akan isu-isu seperti budaya, pendidikan, politik, dan hankam melalui program CSR, secara tidak langsung menggambarkan bahwa mereka memiliki rasa tanggung jawab sebagai warga negara.

\section{c. Hambatan dalam Implementasi CSR}

Implementasi program CSR memiliki beragam hambatan dalam pelaksanaannya. Hambatan bisa muncul sewaktu-waktu baik dalam tahap 
perencanaan hingga tahap implementasi, sehingga diperlukan adanya monitoring dan evaluasi guna meminimalisir hambatan yang berkelanjutan.
Hambatan pelaksanaan CSR yang dihadapi oleh dunia perhotelan di Provinsi DIY serta cara mengatasinya dapat dilihat melalui tabel berikut:

Tabel 1. Hambatan dalam Implementasi CSR Hotel

\begin{tabular}{lcl}
\hline \multicolumn{1}{c}{ Hambatan } & Nama Hotel & \multicolumn{1}{c}{ Cara Mengatasi } \\
\hline Waktu & $\begin{array}{c}\text { Melia Purosani, } \\
\text { Santika Premiere }\end{array}$ & $\begin{array}{l}\text { Pengaturan dan pembagian } \\
\text { jadwal yang pas }\end{array}$ \\
Permintaan yang berlebihan & Inna Garuda & $\begin{array}{l}\text { Koordinasi dan komunikasi } \\
\text { maksimal dengan masyarakat } \\
\text { melalui Serikat Pekerja }\end{array}$ \\
& & Mengatur strategi baru \\
Dana, akibat persaingan & The Jayakarta & bersama manajemen \\
bisnis perhotelan & & Selektif dalam mencaria \\
Ketidaksediaan objek & The Phoenix & kriteria yang pas untuk sasaran \\
sasaran akan CSR yang & & CSR \\
sustainable & & \\
\hline
\end{tabular}

Nama-nama hotel yang tidak terdapat dalam tabel di atas, diartikan tidak memiliki hambatan yang berarti dalam implementasi program CSR mereka. Hotel-hotel tersebut adalah Royal Ambarrukmo, Grand Aston dan juga Sheraton Mustika.

\section{Penutup}

Pelaku bisnis perhotelan di provinsi DIY mendefinisikan CSR sebagai bentuk tanggung jawab sosial perusahaan terhadap lingkungan sekitar. Perusahaan melakukan kegiatan yang berfokus pada kegiatan sosial, sebagai wujud kepedulian dan tanggung jawab mereka terhadap masyarakat. Melalui tiap program CSR yang dilaksanakan, perusahaan hotel merepresentasikan CSR sebagai kegiatan filantropi perusahaan. Implementasi CSR oleh para pelaku bisnis perhotelan di Provinsi DIY termasuk dalam kategori corporate philantrhopy atau filantropi perusahaan, yang juga merupakan praktik bisnis yang memiliki tanggung jawab sosial.

$$
\text { Proses manajerial dan }
$$
pengambilan keputusan dalam program CSR hotel dilihat dari keberadaan CSR sebagai manajemen strategis, pihak yang terlibat dalam pembuatan keputusan, dan isu pilihan. Sebanyak 80\% dari hotel yang diriset menjadikan CSR sebagai manajemen strategis perusahaan. Dengan 
menjadikan CSR sebagai manajemen strategis perusahaan atau dengan kata lain sebagai salah satu kebijakan manajemen, perusahaan berharap bahwa hal ini akan membantu memecahkan masalah. Masalah yang dimaksudkan di sini adalah isu-isu sosial di sekitar lingkungan perusahaan.

Pihak-pihak yang turut terlibat dalam proses pengambilan kebijakan manajerial akan CSR perusahaan hotel adalah pimpinan tertinggi (General Manager), Serikat Pekerja atau Forum Komunikasi, dan juga Tim CSR. Tim CSR adalah gabungan dari divisi-divisi yang turut terlibat berdasarkan tugas dan fungsi, atas hasil koordinasi khusus, yang merupakan penanggung jawab akan CSR. Penanggung jawab CSR perhotelan provinsi DIY berdasarkan penelitian ini sebagian besar adalah HRD dengan jumlah persentase 60\%, dan kemudian PR sebanyak 30\%, yang berkordinasi dengan Serikat Pekerja atau Forum Komunikasi. Hanya sedikit perusahaan hotel di DIY yang membentuk tim khusus untuk menangani pelaksanaan CSR perusahaan.

Isu program yang paling banyak mendapat sorotan dari pihak perhotelan provinsi DIY adalah isu sosial, yang diikuti dengan isu lainnya seperti lingkungan, kesehatan, pendidikan, ekonomi, budaya, politik serta pertahanan dan keamanan. Dengan adanya isu yang diperhatikan oleh perusahaan perhotelan melalui CSR masing-masing, secara tidak langsung maupun tidak langsung membantu atau meringankan tugas pokok dari pihakpihak khusus yang memiliki tanggung jawab, seperti pemerintah.

Hambatan yang dipaparkan oleh sebagian narasumber dalam penelitian ini dapat dikategorikan ke dalam beberapa jenis, yakni waktu, dana, permintaan yang berlebih, serta tidak adanya kesediaan pihak sasaran atas CSR yang bersifat berkelanjutan. Hambatan tersebut diatasi dengan beragam cara, sesuai kendala yang dihadapi. Masalah keterbatasan waktu umumnya diatasi dengan adanya komunikasi dan koordinasi yang baik atas jadwal antara operasional hotel dan CSR. Sedangkan untuk masalah dana, yang pada dasarnya disebabkan oleh situasi persaingan bisnis perhotelan yang sedang berkembang pesat di Yogyakarta, diatasi dengan strategi-strategi tersendiri oleh pihak manajemen hotel.

Selain itu untuk permasalahan akan permintaan yang berlebihan dari masyarakat, pihak hotel mengatasinya dengan mengomunikasikannya pada masyarakat melalui organisasi internal perusahaan, yakni serikat pekerja atau forum komunikasi. Terakhir, untuk masalah sasaran yang tidak bersedia untuk program CSR yang berkelanjutan diatasi dengan lebih selektif menentukan sasaran program yang bisa menyanggupi program CSR yang sustainable, misalkan dalam hal legalitas atau semacamnya. 


\section{Daftar Pustaka}

Hunger, J. D., \& Wheelen, T. L. 2003. Manajemen Strategis (5th Edition ed.). (J. Agung, Penj.) Yogyakarta: Andi.

Nova, Frisan. 2012. Re Public Relations. Jakarta: Media Bangsa.

Prastowo, J., \& M. Huda. 2011. Corporate Social Responsibility, Kunci Meraih Kemuliaan Bisnis. Yogyakarta: Samudra Biru.
Stoner, J. A., \& R. E. Freeman. 1994. Manajemen. (H. Sutojo, Ed., W. W. Bakowatun, \& B. Molan, Terj). Jakarta: Intermedia.

Suharto, P. Edi. 2010. CSR \& COMDEV. Bandung: Alfabeta.

S.U.I.S, 1989. Pengambilan Keputusan (Decision Making). Jakarta: Bina Aksara. 
Jurnal komunikasi, Volume 7, Nomor 1, Oktober 2012 